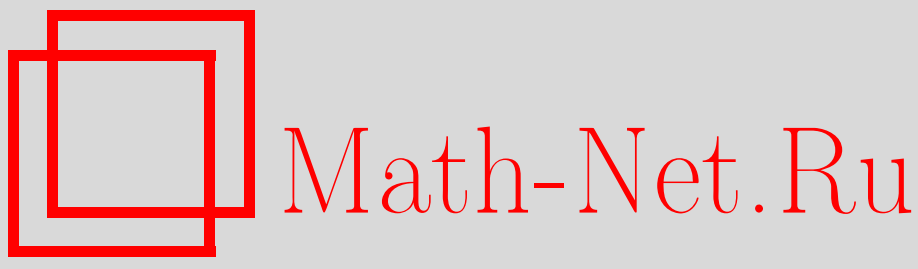

R. Zieliński, A reparametrization of the symmetric $\alpha$-stable distributions and their dispersive ordering, Теория вероятн. и ее примен., 2000, том 45, выпуск 2, 410-411

DOI: https://doi.org/10.4213/tvp475

Использование Общероссийского математического портала Math-Net.Ru подразумевает, что вы прочитали и согласны с пользовательским соглашением http://www . mathnet.ru/rus/agreement

Параметры загрузки:

IP : 54.162 .85 .209

26 апреля 2023 г., 18:00:14

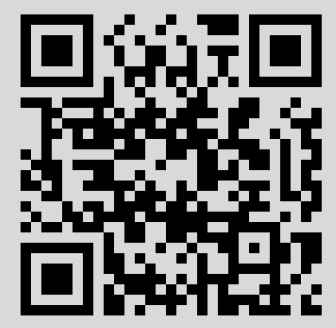


(C) $2000 \mathrm{r}$

ZIELINंSKI R.*

\section{A REPARAMETRIZATION OF THE SYMMETRIC $\alpha$-STABLE DISTRIBUTIONS AND THEIR DISPERSIVE ORDERING}

Для симметричных $\alpha$-устойчивых законов предложена репараметризапия, позволяющая упорядочить по степени рассеяния их функции распределения в зависимости от параметра устойчивости $\alpha$. Рассмотрено одно статистическое приложение.

Ключевые слова и фразы: симметричные устойчивые распределения, характеристическая экспонента, индекс устойчивости, упорядочение по степени рассеяния, оценка Фама-Ролла.

For a symmetric $\alpha$-stable random variable $X$ we shall write $X \sim S(\alpha, \sigma)$ if the characteristic function of $X$ is $\exp \left\{-|\sigma t|^{\alpha} / \alpha\right\}, 0<\alpha \leqslant 2, \sigma>0$.

Theorem. If $X \sim S(\alpha, \sigma)$ and $Y \sim S\left(\alpha^{\prime}, \sigma\right), 0<\alpha^{\prime}<\alpha \leqslant 2$, then $Y \succ X$ in dispersive ordering.

$\mathrm{P} \mathrm{r}$ o of. Due to symmetry around zero and unimodality, it is enough to prove that $\mathbf{P}\{X \leqslant t\}>\mathbf{P}\{Y \leqslant t\}$ for all $t>0$. Consider a positive random variable $V$, independent of $X$, with the Laplace transform $\mathbf{E} e^{-t V}=\exp \left\{-\alpha^{\lambda-1} t^{\lambda} / \lambda\right\}, t>0, \lambda=\alpha^{\prime} / \alpha$. Then $Y$ may be written as $Y=V^{1 / \alpha} X$ (Lemma 1 below). Let $F_{X}$ and $F_{Y}$ denote the distribution functions of $X$ and $Y$, respectively. Now, for $t>0$,

$$
\begin{aligned}
F_{Y}(t) & =\mathbf{P}\{Y \leqslant t\}=\mathbf{P}\left\{V^{1 / \alpha} X \leqslant t\right\}=\mathbf{E}\left[F_{X}\left(\frac{t}{V^{1 / \alpha}}\right) \mid V\right]=\mathbf{E} F_{X}\left(\frac{t}{V^{1 / \alpha}}\right) \\
& \left.<F_{X}\left(t \mathbf{E}\left(\frac{1}{V}\right)^{1 / \alpha}\right) \text { (by concavity of } F_{X}(t) \text { for } t>0\right) .
\end{aligned}
$$

By Lemma 2 below, $\mathbf{E}(1 / V)^{1 / \alpha}<1,0<\alpha \leqslant 2$, and hence $F_{Y}(t)<F_{X}(t)$.

Lemma 1. If $X \sim S(\alpha, \sigma)$ and $V$ is a random variable, independent of $X$, with the Laplace transform $\mathbf{E} e^{-t V}=\exp \left\{-\alpha^{\lambda-1} t^{\lambda} / \lambda\right\}, t>0, \lambda=\alpha^{\prime} / \alpha, 0<\alpha^{\prime}<\alpha \leqslant 2$, then $V^{1 / \alpha} X \sim S\left(\alpha^{\prime}, \sigma\right)$.

$\mathrm{P}$ r $\mathrm{o}$ o f. See [1, Proposition 1.3.1] with trivial modifications.

Lemma 2. If $V$ is a random variable with the Laplace transform $\mathbf{E} e^{-1 V}=$ $\exp \left\{-C t^{\lambda}\right\}, 0<\lambda<1, C=\alpha^{\lambda-1} / \lambda, 0<\alpha \leqslant 2$, then $\mathbf{E}(1 / V)^{1 / \alpha}<1$.

$\mathrm{P}$ r o o f. For $\alpha \in(1,2]$, see [2, Theorem 2.6.3 and Theorem 3.4.3]. After an appropriate change of the scale parameter, Zolotarev's results give us

$$
\mathbf{E}\left(\frac{1}{V}\right)^{1 / \alpha}=\alpha^{(1 / \lambda-1) / \alpha} \lambda^{1 /(\lambda \alpha)} \frac{\Gamma(1+1 /(\lambda \alpha))}{\Gamma(1+1 / \alpha)}
$$

Now, however, the Mellin transform involved, i.e. $\mathbf{E} v^{s}$, is a holomorphic function for $\operatorname{Re} s<\lambda$ and the conclusion holds for all $\alpha \in(0,2)$.

It is interesting that for $\alpha_{n}=1 / n, n=1,2, \ldots$, the result may be obtained directly:

$$
\begin{aligned}
\mathbf{E}\left(\frac{1}{V}\right)^{1 / \alpha_{n}} & =\mathbf{E}\left(\frac{1}{V}\right)^{n}=\int_{0}^{\infty} d x_{n-1} \int_{x_{n-1}}^{\infty} d x_{n-2} \cdots \int_{x_{1}}^{\infty} d t \mathbf{E} e^{-t V} \\
& =C^{-n / \lambda} \frac{\Gamma(1+1 /(\lambda \alpha))}{\Gamma(1+1 / \alpha)} .
\end{aligned}
$$

To complete the proof, observe that, for every fixed $\alpha,(1)$ is an increasing function in $\lambda \in(0,1)$ and for $\lambda=1$ it is equal to 1 .

* Institute of Mathematics, Polish Academy of Sciences, P. O. Box 137, 00-950 Warsaw, Poland; e-mail: rziel@impan.gov.pl 
Comment. Under the usual parametrization with the characteristic function $\exp \left\{-|\sigma t|^{\alpha}\right\}$ the result does not hold. Additionally, a nice property of the reparametrization is that $S(2, \sigma)=N\left(0, \sigma^{2}\right)$ while $S(1, \sigma)$ is the Cauchy distribution with $\sigma$ as the scale parameter.

An application. Let $F_{\alpha}(x)$ denote the distribution function of $X \sim S(\alpha, 1)$. Given $q \in\left(\frac{1}{2}, 1\right)$ and the $q$ th quantile $x_{q}$, the equation $F_{\alpha}\left(x_{q}\right)=q$ with respect to $\alpha$ has the unique solution. This enables one to estimate $\alpha$ by estimating $x_{q}$ which states behind the Fama-Roll [3] estimator. Now however no restrictions on $q$ are needed.

\section{REFERENCES}

1. Samorodnitsky G., Taqqu M.S. Stable Non-Gaussian Random Processes. New YorkLondon: Chapman \& Hall, 1994.

2. Золотарев B. М. Одномерные устойчивые распределения. М.: Наука, 1983, 304 с.

3. Fama E., Roll R. Parameter estimates for symmetric stable distributions. - J. Amer. Statist. Assoc., 1971, v. 66, p. 331-338.

Поступила в редакцию 16.IV.1999

\section{Письмо в редакцию}

В нашей совместной с А. Ло работе [1] была получена оценка близости двух функций распределения $\omega^{2}$-статистик фон Мизеса, одна из которых отвечает наблюдениям с непрерывной функцией распределения, а другая - наблюдениям с равномерным распределением на конечном числе точек. Как следствие было показано, что функция распределения $\omega^{2}$-статистики фон Мизеса отклоняется от функции распределения ее бутстрэп-аппроксимаџии не более, чем на $c(\varepsilon) n^{-1+\varepsilon}$, где $n-$ число наблюдений, каково бы ни было $\varepsilon>0$. Доказательства были основаны, в частности, на одной оценке скорости сходимости в центральной предельной теореме в гильбертовом пространстве из [2]. Если использовать более совершенную, чем в [2], оценку, полученную впоследствии В. Бенткусом и $\Phi$. Гетце в [3], то рассуждения из [1] приводят к следующим более точным результатам: правые части оценок в теореме и ее следствии в [1] могут быть заменены, соответственно, на $c\left(n_{1}^{-1}+m^{-1}+n^{-1}\right)$ и $c^{\prime} n^{-1}$, где $c, c^{\prime}$ суть абсолютные постоянные.

\section{СПИСОК ЛИТЕРАТУРЫ}

1. Lo A. Y., Sazonov V.V. Von Mises $\omega^{2}$-statistic and the bootstrap. - Teopur вероятн. и ее примен., 1995 , т. 40, в. 4, с. 850-858.

2. Залесский Б. А., Сазояов В.В., Ульяков В.В. Нормальная аппроксимация в гильбертовом пространстве, I. - Теория вероятн. и ее примен., 1988, т. 33, в. 2, c. 225-245.

3. Bentkus $V$, Götze $F$. Uniform rates of convergence in the CLT for quadratic forms in multidimensional spaces. - Probab. Theory Relat. Fields, 1997, v. 109, p. 367-416. 